\title{
The Role of Zinc in the Modulation of Neuronal Proliferation and Apoptosis
}

\author{
Ana M. Adamo • Maria P. Zago • Gerardo G. Mackenzie • \\ Lucila Aimo • Carl L. Keen • Alison Keenan • \\ Patricia I. Oteiza
}

Received: 18 March 2009/Revised: 13 May 2009/Accepted: 17 May 2009/Published online: 26 September 2009

(c) The Author(s) 2009. This article is published with open access at Springerlink.com

\begin{abstract}
Although a requirement of zinc ( $\mathrm{Zn}$ ) for normal brain development is well documented, the extent to which $\mathrm{Zn}$ can modulate neuronal proliferation and apoptosis is not clear. Thus, we investigated the role of $\mathrm{Zn}$ in the regulation of these two critical events. A low $\mathrm{Zn}$ availability leads to decreased cell viability in human neuroblastoma IMR-32 cells and primary cultures of rat cortical neurons. This occurs in part as a consequence of decreased cell proliferation and increased apoptotic cell death. In IMR-32 cells, $\mathrm{Zn}$ deficiency led to the inhibition of cell proliferation through the arrest of the cell cycle at the $G_{0} / G_{1}$ phase. $Z n$ deficiency induced apoptosis in both proliferating and quiescent neuronal cells via the intrinsic apoptotic pathway. Reductions in cellular $\mathrm{Zn}$ triggered a translocation of the pro-apoptotic protein Bad to the mitochondria, cytochrome $c$ release, and caspase- 3 activation. Apoptosis is the resultant of the inhibition of the prosurvival extracellular-signal-regulated kinase, the inhibition of nuclear factor-kappa B, and associated decreased expression of
\end{abstract}

Ana M. Adamo and Maria P. Zago contributed equally to this study.

\section{A. M. Adamo · M. P. Zago}

Department of Biological Chemistry, IQUIFIB

(UBA-CONICET), School of Pharmacy and Biochemistry,

University of Buenos Aires, Junín 956,

C1113AAD Buenos Aires, Argentina

G. G. Mackenzie - L. Aimo - C. L. Keen - A. Keenan ·

P. I. Oteiza $(\bowtie)$

Department of Nutrition, University of California, Davis,

One Shields Av., Davis, CA 95616, USA

e-mail: poteiza@ucdavis.edu

G. G. Mackenzie · P. I. Oteiza

Department of Environmental Toxicology, University

of California, Davis, Davis, CA 95616, USA antiapoptotic proteins, and to a direct activation of caspase3. A deficit of $\mathrm{Zn}$ during critical developmental periods can have persistent effects on brain function secondary to a deregulation of neuronal proliferation and apoptosis.

Keywords Zinc - Neuron - Proliferation - Apoptosis · Caspase · Nuclear factor-kappa B (NF- $\kappa \mathrm{B})$. Extracellular-signal-regulated kinase (ERK) . Zinc deficiency · Cortical neuron · Bad

$\begin{array}{ll}\text { Abbreviations } \\ \text { Cdks } & \text { Cyclin-dependent kinases } \\ \text { DTPA } & \text { Diethylenetriamine pentaacetic acid } \\ \text { EMSA } & \text { Electrophoretic mobility shift assay } \\ \text { ERK } & \text { Extracellular-signal-regulated kinase } \\ \text { FBS } & \text { Fetal bovine serum } \\ \text { MAPK } & \text { Mitogen-activated kinases } \\ \text { NF- } \kappa \text { B } & \text { Nuclear factor-kappa B } \\ \text { Zn } & \text { Zinc }\end{array}$

\section{Introduction}

Zinc ( $\mathrm{Zn})$ is an essential nutrient that has multiple roles in the nervous system (Frederickson et al. 2005); deficits of this nutrient can result in numerous diverse pathologies (Rogers et al. 1990; Keen et al. 1995; Sandstead 2003). Zn exists largely bound to proteins, and numerous enzymes require $\mathrm{Zn}$ including DNA and RNA polymerases, several enzymes in the intermediary metabolism, and most metalloproteinases. $\mathrm{Zn}$ is also a structural component of a family of Zn-binding proteins known as Zn-finger proteins that act as DNA-binding transcription factors. While protein 
bound $\mathrm{Zn}$ is important, large amounts of $\mathrm{Zn}$ are not protein bound. For example, about $10 \%$ of $\mathrm{Zn}$ in the nervous system is associated with pre-synaptic vesicles of glutaminergic neurons; this $\mathrm{Zn}$, which is not protein bound, is released as free $\mathrm{Zn}$ into the synaptic cleft where it can modulate the activity of a variety of post-synaptic receptors (Frederickson et al. 2005).

In rodent models, severe $\mathrm{Zn}$ deficiency throughout pregnancy can result in multiple brain malformations (Hurley and Swenerton 1966), and deficits of this nutrient during the early postnatal period can affect the number and differentiation of neurons in the cerebellum (Dvergsten et al. 1983, 1984a, b). Mild Zn deficiency can result in alterations in learning, attention, and memory in rodents and non-human primates (reviewed in Golub et al. 1995, 2000). In humans, maternal dietary $\mathrm{Zn}$ intakes during pregnancy have been reported to be inversely associated with the head circumference of the infant at birth (Lagiou et al. 2005), and Zn supplementation has been associated with larger head circumferences in infants from women with low body mass index (Goldenberg et al. 1995). There is a growing body of evidence that supports the concept that in humans, suboptimal $\mathrm{Zn}$ nutrition during development is associated with altered neonatal/infant behavior, cognitive, and motor performance (Kirksey et al. 1994; Bentley et al. 1997; Penland et al. 1997; Gardner et al. 2005).

$\mathrm{Zn}$ plays an essential role in cell proliferation (MacDonald et al. 1998; Wang et al. 2002; Wong et al. 2007; Corniola et al. 2008) and apoptosis (reviewed in Truong-Tran et al. 2003; Clegg et al. 2005; Fraker 2005; Corniola et al. 2008) in different tissues and cell types. The regulation of cell proliferation by $\mathrm{Zn}$ can occur at different levels including the requirement of $\mathrm{Zn}$ for the activity of enzymes involved in DNA synthesis (i.e., deoxythymidine kinase), and the modulation of regulatory signals directly, as well as indirectly, through its effects on the hormonal regulation of cell division. Illustrative of this, the pituitary growth hormone-insulin-like growth factor-1 axis is responsive to $\mathrm{Zn}$ status (MacDonald 2000), although its role in $\mathrm{Zn}$ deficiency-associated decreases in cell proliferation is an issue of controversy (Ninh et al. 1998; Wang et al. 2002). Low cellular $\mathrm{Zn}$ concentrations can trigger apoptosis in numerous cell types, including fibroblasts, hepatocytes, T-cell precursors, glioma, and testicular cells. The mechanisms involved in the induction of apoptosis secondary to $\mathrm{Zn}$ deficiency are multiple, and differ among different cell types. Zn can act as an inhibitor of caspase-3, a cysteine protease that is central in apoptosis cleaving key proteins [e.g., poly(ADPribose) polymerase (PARP)] that continue the apoptotic cascade (reviewed in Truong-Tran et al. 2001). Zn deficiency can also induce apoptosis by disrupting growth factors signal transduction pathways mediated by receptor tyrosine kinases (Clegg et al. 2005).
While somewhat controversial (Zago et al. 2005), it has also been proposed that an increase in cell oxidants triggers apoptosis (Clegg et al. 2005).

Studies with experimental animals, as well as in cell models, have shown that neurons can be particularly affected by a low availability of $\mathrm{Zn}$. In rats, postnatal $\mathrm{Zn}$ deficiency impaired the normal development of the cerebellum, affecting the number and differentiation of Purkinje, basket, stellate, and granule cells (Sandstead 2003). In human neuroblastoma IMR-32 cells, we observed that with $\mathrm{Zn}$ deficiency there is a reduction in cell viability, with evidence of increased apoptotic death (Verstraeten et al. 2004; Zago et al. 2005).

In the nervous system, cell proliferation and apoptosis actively occur during the perinatal period, and are critical for normal neurodevelopment. Alterations in these tightly regulated events can affect the function of the nervous system latter in life. Given the close interrelationships between cell proliferation and death in the development of the nervous system, and to better understand the role of $\mathrm{Zn}$ in this process, in this study we investigated if a low $\mathrm{Zn}$ availability can affect neuronal proliferation and survival. As experimental models, we investigated the effects of $\mathrm{Zn}$ deficiency on neuronal proliferation in human neuroblastoma cells (IMR-32), and on apoptosis in IMR-32 cells, and primary cultures of differentiated rat cortical neurons. We show that with a deficit of $\mathrm{Zn}$, there is an inhibition of neuronal cell proliferation that is secondary to an arrest at the $G_{0} / G_{1}$ phase of the cell cycle. Interestingly, in proliferating as well as in quiescent neurons, $\mathrm{Zn}$ deficiency triggers apoptotic neuronal death. The apoptosis occurs via the intrinsic pathway which can be a consequence of extracellular-signal-regulated kinase (ERK) inhibition, caspase- 3 activation, and the down-regulation of nuclear factor-kappa B (NF- $\kappa \mathrm{B})$-dependent anti-apoptotic genes.

\section{Materials and Methods}

\section{Materials}

The IMR-32 neuroblastoma cells were obtained from the American Type Culture Collection (Rockville, MA, USA). Cell culture media and reagents were purchased from Invitrogen Life Technologies (Carlbad, CA, USA). The CellTiter-Glo Luminescent Cell Viability Assay, the oligonucleotides containing the consensus sequence for NF- $\kappa$ B (5'-AGTTGAGGGGACTTTCCCAGGC- $\left.3^{\prime}\right)$ and OCT-1, and the reagents for the electrophoretic mobility shift assay (EMSA) assay were obtained from Promega (Madison, WI, USA). Polyclonal antibodies for Akt, phosphorylated Akt (Ser 473), Bcl-2, c-myc, c-IAP1, and XIAP, and phosphorylated Bad (Ser 112 or Ser 136) were 
obtained from Cell Signaling Technology (Beverly, MA, USA). Antibodies for p53, ERK1/2, phosphorylated ERK, p21, cyclin D1 and E, PARP, Bad, cytochrome $c$, Bcl-xL, and $\beta$-tubulin were from Santa Cruz Biotechnology (Santa Cruz, CA, USA). Polyvinylidene difluoride (PVDF) membranes were obtained from BIO-RAD (Hercules, CA, USA). Merocyanine 540 and propidium iodide were obtained from Molecular Probes (Eugene, OR, USA). The ECL Plus western blotting detection reagents were from GE Healthcare (Piscataway, NJ, USA). The APO-BrdUTM kit and BD CycletestTM Plus DNA reagent kit were obtained from Pharmingen-Becton-Dickinson Co. (San Diego, CA, USA). The ApoAlert-Caspase-3 Assay was purchased from Clontech (Mount View, CA, USA). All other reagents were from the highest quality available and were purchased from Sigma (St. Louis, MO, USA).

\section{Cell Cultures and Incubation}

Zn-deficient fetal bovine serum (FBS) was prepared by chelation with diethylenetriamine pentaacetic acid (DTPA) as previously described (Oteiza et al. 2000; Mackenzie et al. 2002b). The chelated FBS was subsequently diluted with complex medium or DMEM to a final concentration of $3 \mathrm{mg}$ protein $/ \mathrm{ml}$ to match the protein concentration of the control non-chelated medium [10\% (v/v) FBS]. The concentration of $\mathrm{Zn}$ in the deficient medium was $1.5 \mu \mathrm{M}$. Aliquots of the $\mathrm{Zn}$-deficient media were supplemented with $\mathrm{ZnSO}_{4}$ to a final $\mathrm{Zn}$ concentration of $15 \mu \mathrm{M}$.

IMR-32 cells were cultured at $37^{\circ} \mathrm{C}$ in complex medium [55\% (v/v) DMEM high glucose, 30\% (v/v) Ham F-12, $5 \%(\mathrm{v} / \mathrm{v}) \alpha$-MEM] supplemented with $10 \%(\mathrm{v} / \mathrm{v})$ FBS and antibiotics-antimycotic $(50 \mathrm{U} / \mathrm{ml}$ penicillin, $50 \mu \mathrm{g} / \mathrm{ml}$ streptomycin, and $0.125 \mu \mathrm{g} / \mathrm{ml}$ amphotericin B). Cells were grown in control medium [complex medium containing 10\% (v/v) non-chelated FBS] until 90\% confluence. Depending on the experimental conditions, synchronized or unsynchronized IMR-32 cells were incubated in control non-chelated medium or in chelated media containing 1.5 or $15 \mu \mathrm{M} \mathrm{Zn}$. Cells were harvested at different time points (6-48 h) depending on each experiment. We previously reported that the incubation of IMR-32 cells in media containing low $\mathrm{Zn}$ concentrations (1.5 and $5 \mu \mathrm{M} \mathrm{Zn})$ results in a reduction of cellular labile $\mathrm{Zn}$ pools within $3 \mathrm{~h}$ (Mackenzie et al. 2002a).

For the isolation of cortical neurons, timed-pregnant Sprague-Dawley rats were obtained from Charles Rivers Laboratories (Wilmington, MA, USA). All animal procedures were in agreement with standards for the care of laboratory animals as outlined in the NIH Guide for the Care and Use of Laboratory Animals. Primary cortical cultures were prepared from E19 embryos according to Banker and Goslin (1998). In brief, embryos were rapidly removed under sterile conditions, and after removal of the skull and meninges, the cerebral hemispheres were dissected out and placed in Hanks' balanced salt solution prewarmed to $37^{\circ} \mathrm{C}$. Cortical tissue was dissociated by enzymatic digestion $(0.025 \% \mathrm{w} / \mathrm{v}$ trypsin). Trypsinization was stopped by the addition of Hanks' solution containing $20 \%$ (v/v) FBS, and the tissue was mechanically dissociated in Hanks' balanced salt solution containing $0.004 \%$ (w/v) DNAse with Pasteur pipettes of different diameters. The resulting cell suspension was centrifuged at $200 \times g$ for $5 \mathrm{~min}$. The cells were resuspended in a known volume of Neurobasal culture medium supplemented with $2 \%(\mathrm{v} / \mathrm{v})$ serum-free additive B27, and plated on poly-L-lysine-coated dishes. Cell cultures were incubated at $37^{\circ} \mathrm{C}$ in an atmosphere of $95 \%$ (v/v) air, $5 \%(\mathrm{v} / \mathrm{v}) \mathrm{CO}_{2}$ with $90-95 \%(\mathrm{v} / \mathrm{v})$ humidity. After $24 \mathrm{~h}$ in culture, the media were replaced by DMEM high glucose supplemented with $10 \%$ (v/v) FBS. After $72 \mathrm{~h}$, cell cultures were supplemented with $40 \mu \mathrm{M}$ cytosine- $\beta$-D-arabinoside for $24 \mathrm{~h}$ to inhibit non-neuronal cell proliferation. After 7-9 days in culture, the media were replaced by control non-chelated medium, or chelated medium containing 1.5 or $15 \mu \mathrm{M} \mathrm{Zn}$, and cells were further incubated for 6-24 h depending on the experiment.

Cell viability for IMR-32 and cortical neurons was measured evaluating the cell ATP content (CellTiter-Glo Luminescent Cell Viability) according to manufacturer's protocol.

\section{Evaluation of Cell Cycle Progression}

For synchronization, IMR-32 cells were serum-starved for $48 \mathrm{~h}$ in complex medium containing $0.1 \%$ (v/v) FBS. Re-entry into $G_{1}$ phase of the cell cycle was initiated by replacement of the starvation medium with complete or chelated media containing 1.5 or $15 \mu \mathrm{M} \mathrm{Zn}$. After 0,12 , 16 , and $24 \mathrm{~h}$, cells were collected, washed and the analysis of nuclear DNA was performed using the Cycletest ${ }^{\mathrm{TM}}$ Plus DNA Reagent Kit. Propidium iodide-stained nuclei were analyzed by flow cytometry on a Becton-Dickinson cytometer and the percentage of cells in the $\mathrm{G}_{0}-\mathrm{G}_{1}, \mathrm{~S}$, and $\mathrm{G}_{2}-\mathrm{M}$ phases of the cell cycle were determined by using the Mod Fit LT cell cycle analysis software (Verity Software, Topsham, ME, USA).

\section{Western Blot}

Cells were washed in PBS and whole cell extracts were prepared by lysis in $50 \mathrm{mM}$ Hepes buffer (pH 7.4), containing $150 \mathrm{mM} \mathrm{NaCl}, 0.5 \mathrm{mM}$ EDTA, $2 \%$ (v/v) Igepal, phosphatase inhibitors $(1 \mathrm{mM}$ sodium pervanadate, $100 \mu \mathrm{M}$ $\mathrm{NaF}$ ), and protease inhibitors ( $1 \mathrm{mM}$ PMSF, $5 \mu \mathrm{g} / \mathrm{ml}$ leupeptin, $1 \mathrm{mg} / \mathrm{l}$ pepstatin, and $10 \mu \mathrm{g} / \mathrm{ml}$ aprotinin). Lysates were exposed to one cycle of freezing and thawing, 
incubated for $30 \mathrm{~min}$ on ice and centrifuged at $15000 \times g$ for $30 \mathrm{~min}$. Nuclear fractions were isolated as previously described (Mackenzie et al. 2002b). The protein content in the samples was measured according to Bradford (1976).

Aliquots of total or nuclear fractions containing 25-50 $\mu \mathrm{g}$ of protein were separated by SDS-PAGE [10-12.5\% (w/v) acrylamide] (Laemmli 1970) blotted onto PVDF membranes and subsequently probed with the different primary antibodies followed by a secondary horseradish peroxidase-conjugated antibody. The bands were visualized by enhanced chemiluminescence (ECL plus, Amersham Biosciences, Piscataway, NJ, USA) and measured using a Phosphoimager 840 (GE Healthcare).

\section{Electrophoretic Mobility Shift Assay}

Nuclear fractions were isolated as previously described (Mackenzie et al. 2006a). For the EMSA, the oligonucleotides containing the consensus sequences for NF- $\kappa \mathrm{B}$ or OCT-1 were end labeled with $\left[\gamma^{-32} \mathrm{P}\right]$ ATP using T4 polynucleotide kinase and purified using Chroma Spin-10 columns. Samples were incubated with the corresponding labeled oligonucleotide $(20000-30000 \mathrm{cpm})$ for $20 \mathrm{~min}$ at room temperature in $1 \times$ binding buffer [ $5 \times$ : $50 \mathrm{mM}$ Tris$\mathrm{HCl}$ buffer, $\mathrm{pH} 7.5$, containing $20 \%$ (v/v) glycerol, $5 \mathrm{mM}$ $\mathrm{MgCl}_{2}, 2.5 \mathrm{mM}$ EDTA, $2.5 \mathrm{mM}$ DTT, $250 \mathrm{mM} \mathrm{NaCl}$, and $0.25 \mathrm{mg} / \mathrm{ml}$ poly $(\mathrm{dI}-\mathrm{dC})]$. The products were separated by electrophoresis in a $6 \%(\mathrm{w} / \mathrm{v})$ non-denaturing polyacrylamide gel using $0.5 \times \mathrm{TBE}(45 \mathrm{mM}$ Tris/borate, $1 \mathrm{mM}$ EDTA) as the running buffer. The gels were dried and radioactivity was measured using a Phosphoimager 840 .

\section{Evaluation of Apoptosis}

Assay of Caspase-3 Activity

Caspase-3 activity was determined in cell lysates after incubating IMR-32 cells for 12, 24, 36, and $48 \mathrm{~h}$, and cortical neurons for 12,18 , and $24 \mathrm{~h}$, in control or chelated media containing 1.5 or $15 \mu \mathrm{M} \mathrm{Zn}$. Caspase-3 activity was measured using the ApoAlert-Caspase-3 Assay following manufacturer's protocol.

Caspase-3 activity was also determined measuring the proteolytic processing of full-length PARP [poly(ADPribose) polymerase] by Western blot analysis as described above.

\section{TUNEL Assay}

Apoptotic nuclei were identified in IMR-32 and cortical neurons after 48 and $24 \mathrm{~h}$ of incubation, respectively, in control or chelated media containing 1.5 or $15 \mu \mathrm{M} \mathrm{Zn}$ by evaluating DNA breaks with the TUNEL assay, either by confocal fluorescence microscopy (laser scanning confocal microscope Nikon D-ECLIPSE C1si) or by flow cytometry. For analysis by flow cytometry, control and treated cells were collected in their culture medium, pelleted by centrifugation at $300 \times g$ for $5 \mathrm{~min}$ and rinsed with PBS. Cells were fixed with $1 \%(\mathrm{w} / \mathrm{v})$ paraformaldehyde in PBS and after $15 \mathrm{~min}$ on ice, washed, and resuspended in PBS. Seventy percent $(\mathrm{v} / \mathrm{v})$ cold ethanol was added to the suspension and placed overnight at $-20^{\circ} \mathrm{C}$. After centrifugation, the cells were washed and resuspended in $50 \mu \mathrm{l}$ of the staining solution containing the terminal deoxynucleotidyl transferase enzyme and FITC-dUTP and incubated for $2 \mathrm{~h}$ at $37^{\circ} \mathrm{C}$. At the end of the incubation time, the cells were washed, resuspended in $0.5 \mathrm{ml}$ of the propidium iodide/ RNAse solution, and analyzed on a Becton-Dickinson flow cytometer.

\section{Translocation of Phosphatidyl Serine to the Outer Layer of the Plasma Membrane}

The translocation of phosphatidyl serine was evaluated measuring the cell binding of merocyanine (Verstraeten et al. 2004). IMR-32 $\left(1 \times 10^{4}\right.$ cells $)$ cells suspended in $0.3 \mathrm{ml}$ of $50 \mathrm{mM}$ Hepes buffer ( $\mathrm{pH} 7.4$ ) containing $125 \mathrm{mM} \mathrm{KCl}$ were added with $10 \mu \mathrm{M}$ merocyanine, and incubated at room temperature for $10 \mathrm{~min}$ in the darkness. Merocyanine binding to phosphatidylserine was evaluated as the increase in the

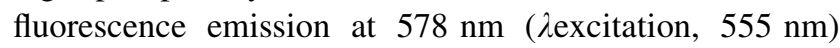
using an SFM-25 Kontron fluorometer (Kontron Instruments s.p.A, Milan, Italy). To evaluate DNA content, cells were disrupted by a 30-min incubation in presence of $0.1 \%(\mathrm{v} / \mathrm{v})$ Igepal, and incubated for further $20 \mathrm{~min}$ with $50 \mu \mathrm{M}$ pro-

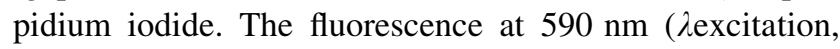
$538 \mathrm{~nm}$ ) was measured, and results are expressed as the merocyanine/propidium iodide fluorescence ratio.

\section{Cytochrome c Release}

To characterize the release of cytochrome $c, 18 \mathrm{~h}$ after incubating IMR-32 cells in the presence of control or chelated media containing 1.5 or $15 \mu \mathrm{M} \mathrm{Zn}$, cells were harvested in their culture medium, pelleted by centrifugation at $300 \times g$ for $5 \mathrm{~min}$, rinsed with PBS, and resuspended in $250 \mu \mathrm{l}$ of $20 \mathrm{mM}$ Hepes buffer ( $\mathrm{pH} 7.5$ ) containing $10 \mathrm{mM} \mathrm{KCl}, 1.5 \mathrm{mM} \mathrm{MgCl} 2,1 \mathrm{mM}$ EDTA, $1 \mathrm{mM}$ EGTA, $1 \mathrm{mM}$ dithiothreitol, $250 \mathrm{mM}$ sucrose, and a mixture of protease inhibitors. Cells were homogenized with a glass Pyrex homogenizer and centrifuged at $1000 \times g$ for $10 \mathrm{~min}$ to remove nuclei and unbroken cells. The resulting supernate was subjected to a $10000 \times g$ centrifugation for $20 \mathrm{~min}$ at $4{ }^{\circ} \mathrm{C}$ and the pellet, corresponding to the mitochondrial fraction, was solubilized in $50 \mu \mathrm{l}$ of $10 \mathrm{mM}$ Tris buffer ( $\mathrm{pH} 8$ ), $0.05 \%$ (v/v) Igepal, and $5 \mathrm{mM} \mathrm{CaCl}_{2}$. The resulting 
supernate was centrifuged at $100000 \times g$ for $1 \mathrm{~h}$ at $4^{\circ} \mathrm{C}$ to obtain the cytosolic fraction. Cytochrome $c$ and Bad content in mitochondrial and cytosolic fractions were measured by Western blot analysis as described above.

\section{Statistical Analysis}

One-way analysis of variance (ANOVA) with subsequent post-hoc comparisons by Scheffe were performed using Statview 5.0 (SAS Institute, Cary, NC, USA). A $P$-value $<0.05$ was considered statistically significant. Values are given as means \pm SEM.

\section{Results}

\section{A Decrease in Zn Availability Decreases IMR-32 Neuroblastoma Cell Viability}

To investigate the requirement of $\mathrm{Zn}$ for neuronal proliferation, the human neuroblastoma cell line IMR-32 was used as a model. These cells can be differentiated in vitro to a phenotype of cortical neurons, thus they can complement observations made using primary cortical neurons.

The effects of low extracellular $\mathrm{Zn}$ concentrations on IMR-32 cell viability were initially investigated (Fig. 1). IMR-32 cells were incubated for $12-48 \mathrm{~h}$ in control medium or in chelated medium containing 1.5 or $15 \mu \mathrm{M} \mathrm{Zn}$, and cell viability was evaluated measuring the intracellular content of ATP. Cell viability was similar among the groups after $12 \mathrm{~h}$ of incubation, but at 24 and $48 \mathrm{~h}$, cell viability was significantly lower $(P<0.05)$ for the cells

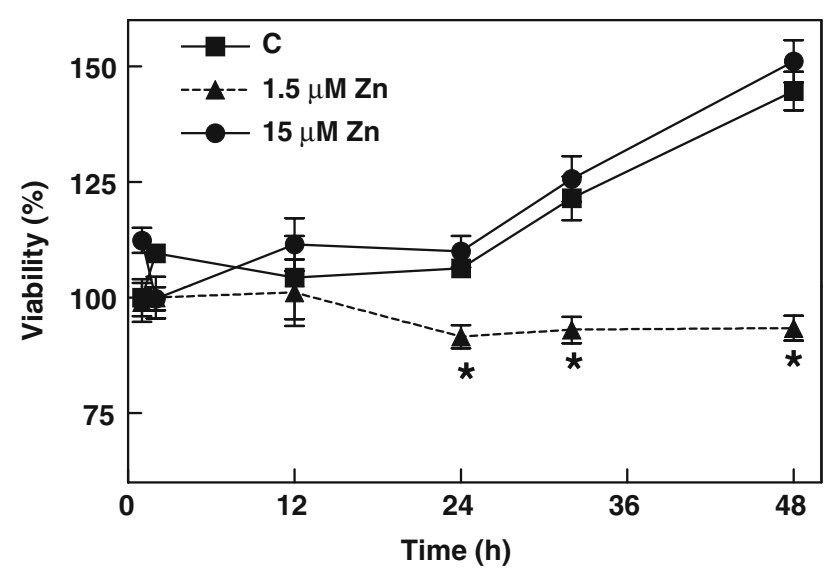

Fig. 1 The influence of Zn deficiency on IMR-32 cell viability. IMR32 cells were incubated for $1-48 \mathrm{~h}$ in control non-chelated medium (C) or chelated media containing 1.5 or $15 \mu \mathrm{M} \mathrm{Zn}$, after which cell viability was measured as described in "Materials and methods" section. Results are shown as means \pm SEM of four independent experiments. * Significantly different compared to $C$ and $15 \mu \mathrm{M} \mathrm{Zn}$ groups $(P<0.01$, one-way ANOVA test $)$ incubated in the $\mathrm{Zn}$ deficient $(1.5 \mu \mathrm{M} \mathrm{Zn})$ media compared to controls (15 and 35\%, respectively). The finding that cell viability was similar for the groups incubated in chelated medium supplemented with $15 \mu \mathrm{M} \mathrm{Zn}$ and in control medium at all the time points investigated, suggesting that the low cell viability found in the $1.5 \mathrm{Zn}$ group can be attributed to the decrease in $\mathrm{Zn}$ availability. Under similar experimental conditions, we previously described that the incubation of cells in media containing $1.5 \mu \mathrm{M} Z n$ leads to a rapid decrease in, labile, as well as total, $\mathrm{Zn}$ concentrations (Mackenzie et al. 2002a, 2006a).

A Decrease in Zn Availability Inhibits IMR-32 Neuroblastoma Cell Proliferation

The observed decrease in IMR-32 cell viability in cells exposed to medium containing $1.5 \mu \mathrm{M} \mathrm{Zn}$ could have occurred secondary to a requirement of $\mathrm{Zn}$ for cell proliferation and/or to the occurrence of apoptotic cell death. To investigate this, the progression of the cell cycle was investigated. Cell cycle in IMR-32 cells occurs within $24 \mathrm{~h}$, and the entry into the S phase occurs between 12 and $16 \mathrm{~h}$ (30 and 35\% of cells in S phase, respectively) (data not shown). The effects of varying extracellular $\mathrm{Zn}$ concentrations on the distribution of cells in $S, G_{0}-G_{1}$, and $\mathrm{G}_{2}-\mathrm{M}$ phases were characterized after $0,9,12,16$, and $24 \mathrm{~h}$, respectively. At time 0 , in synchronized cells, approximately $75 \%$ of the cells were in $\mathrm{G}_{0}-\mathrm{G}_{1}$ phase of the cell cycle. At $12 \mathrm{~h}$, there were no significant differences in the proportion of cells in $\mathrm{G}_{1}, \mathrm{~S}$, and $\mathrm{G}_{2}-\mathrm{M}$ phases among the groups. At $16 \mathrm{~h}$ (Fig. 2a), cells incubated in the $1.5 \mu \mathrm{M}$ $\mathrm{Zn}$ media exhibited a significant $(P<0.05)$ growth arrest in $\mathrm{G}_{1}$ phase $\left(74 \pm 1,61 \pm 1\right.$, and $59 \pm 2 \%$ cells in $\mathrm{G}_{0}-\mathrm{G}_{1}$ phase for the $1.5,15 \mu \mathrm{M} \mathrm{Zn}$, and control cells, respectively) (Fig. 2a).

Key proteins involved in the control of the $\mathrm{G}_{1} / \mathrm{S}$ checkpoint of the cell cycle were subsequently investigated. In synchronized IMR-32 cells, the incubation in control medium for $9 \mathrm{~h}$ was associated with a marked reduction in p21; a protein that inhibits $\mathrm{G}_{1}-\mathrm{S}$ transition, p21 levels remained low for the subsequent $15 \mathrm{~h}$. In the cells incubated in medium containing $1.5 \mu \mathrm{M} \mathrm{Zn}$, p21 levels remained relatively high throughout the $24 \mathrm{~h}$ culture period. Consistent with the above, the levels of p53, a protein that positively regulates $\mathrm{p} 21$, were higher in IMR-32 cells incubated in $1.5 \mu \mathrm{M} \mathrm{Zn}$ medium compared to controls at all time points $(6-24 \mathrm{~h})$. In concordance with the arrest of the cell cycle in $\mathrm{G}_{1}$ phase, $\mathrm{Zn}$ deficiency resulted in a reduction in cyclin $\mathrm{D}_{1}$ and $\mathrm{E}$ protein levels after $6 \mathrm{~h}$ of incubation, the levels remained low throughout the $24 \mathrm{~h}$ study period (Fig. 2b). The mitogen-activated kinase (MAPK) ERK has an important role in the regulation of cell proliferation. The incubation of IMR-32 cells in $1.5 \mu \mathrm{M} \mathrm{Zn}$ medium was 
a

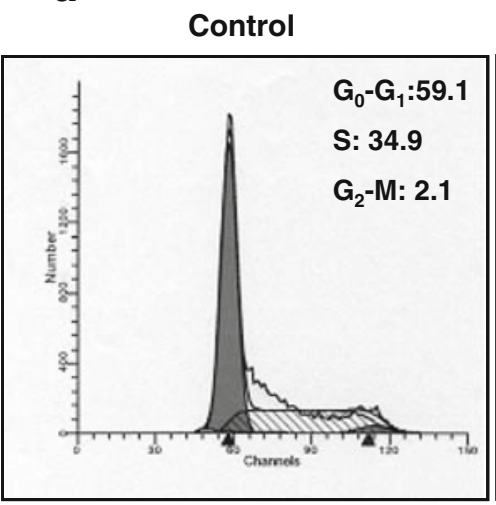

$1.5 \mu \mathrm{M} \mathrm{Zn}$

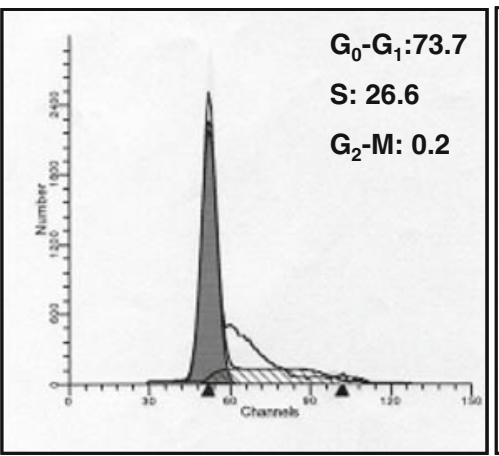

$15 \mu \mathrm{M} Z \mathbf{Z n}$

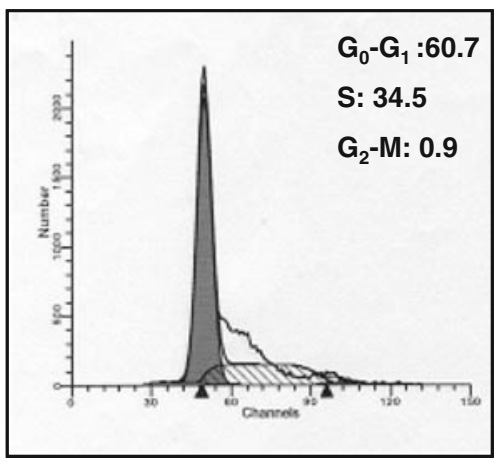

b

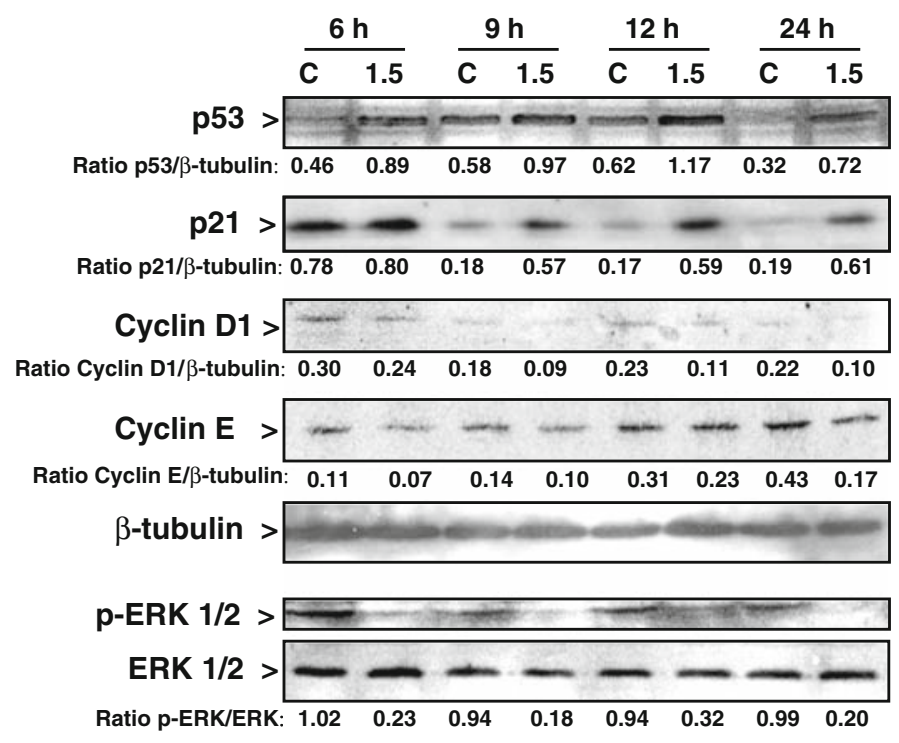

Fig. $2 \mathrm{Zn}$ deficiency affects the distribution of events in the IMR-32 cell cycle. a Synchronized IMR-32 cells were incubated for $16 \mathrm{~h}$ in control non-chelated medium $(C)$ or chelated media containing 1.5 or $15 \mu \mathrm{M} \mathrm{Zn}$. The evaluation of cell cycle progression was done as described in "Materials and methods" section. The histograms show DNA staining by propidium iodide. The figure shows representative FACS profiles of the distribution of cells in $G_{0}-G_{1}, S$, and $G_{2}-M$ phases from four independent experiments. b Western blot for p53,

associated with a marked decrease in ERK phosphorylation that occurred throughout the $24 \mathrm{~h}$ period (Fig. 2b).

A Decrease in Zn Availability Induces Apoptotic Death in IMR-32 Neuroblastoma Cells and Primary Cortical Neurons

The involvement of apoptotic cell death in the decreased cell viability associated with Zn deficiency was assessed by evaluating different steps in the apoptotic cascade, the activation of the effector caspase-3 (caspase-3 activity and degradation of its substrate, PARP), DNA fragmentation, and the translocation of phosphatidyl serine to the outer cell membrane leaflet. cyclins E and D1, p-ERK, ERK, and tubulin in total cell fractions, and p21 (nuclear fractions), in synchronized cells incubated in control $(C)$ or the media containing $1.5 \mu \mathrm{M} \mathrm{Zn}$ (1.5) for the indicated period of time. The figure shows representative images. Numbers under the figures are means from three independent experiments. Values for the $1.5 \mathrm{Zn}$ group are significantly different $(P<0.05)$ compared to controls at all the times measured for p53, cyclins D1 and E, and p-ERK, and between 9 and $24 \mathrm{~h}$ for $\mathrm{p} 21$

For IMR-32 cells, their incubation in low $\mathrm{Zn}$ medium led to a time-dependent activation of caspase-3 (Fig. 3a, b). The increased activation of caspase-3, measured as enzyme activity, was significant after incubating the cells for $24 \mathrm{~h}$ in the $1.5 \mu \mathrm{M} \mathrm{Zn}$ medium compared to the control cells. Caspase-3 activity remained elevated for the subsequent $24 \mathrm{~h}$ (threefold higher than in controls) (Fig. 3a). When cells were simultaneously incubated for $24 \mathrm{~h}$ in $1.5 \mu \mathrm{M} \mathrm{Zn}$ medium supplemented with the antioxidant $\alpha$-lipoic acid $(0.5 \mathrm{mM})$, the activity of caspase- 3 remained high (100 $\pm 8,176 \pm 6$, and $184 \pm 20$, for cells incubated in the following media: control, $1.5 \mu \mathrm{M} \mathrm{Zn}$, and 1.5 $\mu \mathrm{M} \mathrm{Zn}$ added with $\alpha$-lipoic acid, respectively). The activation of caspase-3 in the $1.5 \mu \mathrm{M} \mathrm{Zn}$ group was also observed when 
a
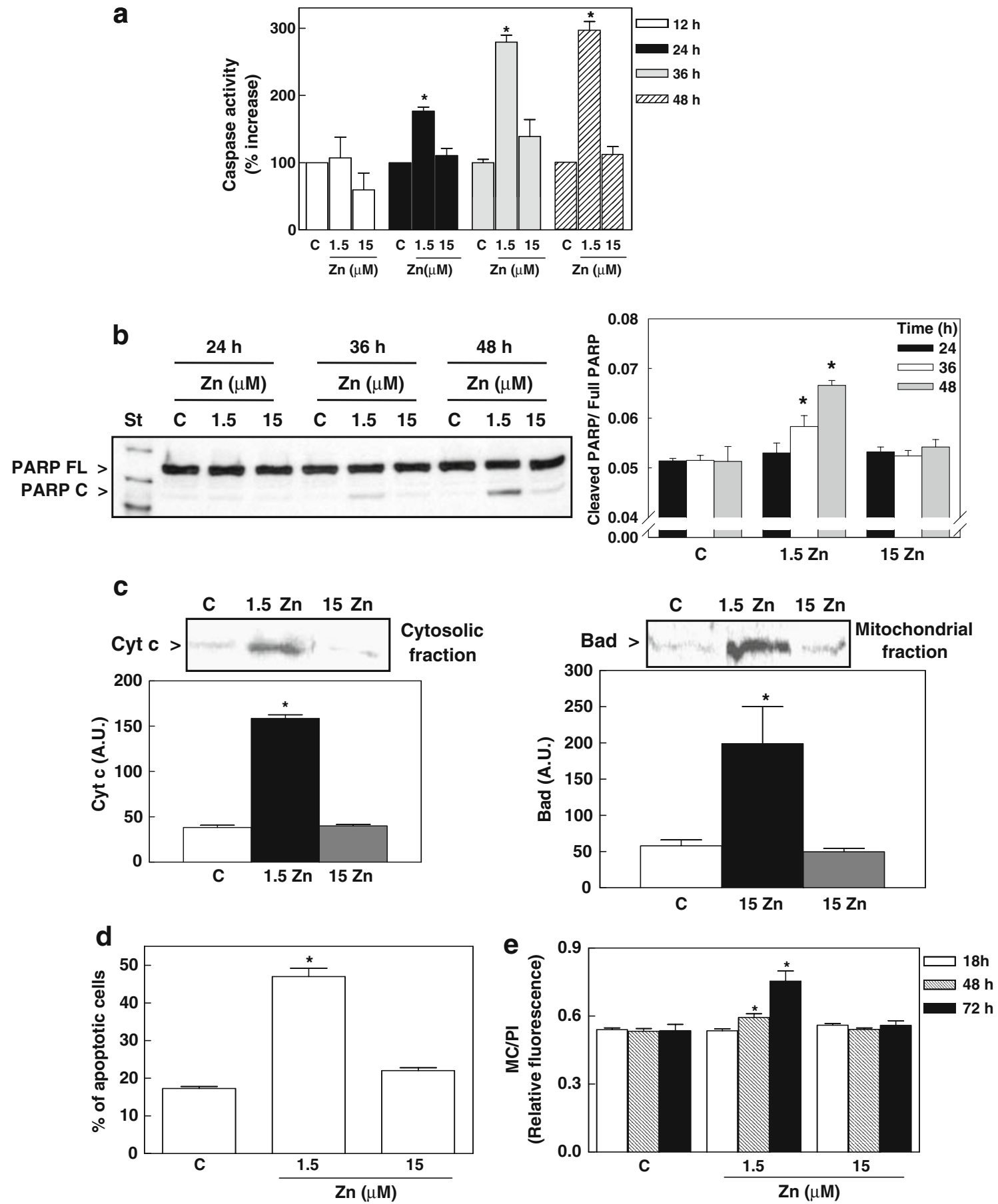

Fig. $3 \mathrm{Zn}$ deficiency induces apoptotic cell death in IMR-32 cells. Cells were incubated in control non-chelated medium $(C)$ or chelated media containing $1.5(1.5 \mathrm{Zn})$ or $15 \mu \mathrm{M}(15 \mathrm{Zn}) \mathrm{Zn}$ for the different periods of time. a Caspase-3 activity after $12,24,36$, and $48 \mathrm{~h}$ of incubation, in the different experimental conditions. b Western blot for full-length and cleaved-PARP in IMR-32 cells incubated in the corresponding media. One representative image out of three independent experiments is shown. c Western blots for $\mathrm{Bad}$ and cytochrome $c$ (cyt $c$ ) in cytosolic or mitochondrial fractions after $18 \mathrm{~h}$ incubation. Representative images out of two to three independent experiments are shown. d DNA nicks were evaluated with the

TUNEL staining after $48 \mathrm{~h}$ incubation, and the percentage of apoptotic cells was calculated. Results are shown as means \pm SEM of four independent experiments. e After 18, 48, and $72 \mathrm{~h}$ incubation in the corresponding media, the amount of phosphatidylserine in the outer layer of the cell membrane was evaluated fluorometrically measuring merocyanine 540 (MC) binding, and is expressed relative to the amount of DNA measured as propidium iodide (PI) fluorescence. All results are shown as means \pm SEM of two to four independent experiments. * Significantly different compared to $C$ and $15 \mu \mathrm{M} Z \mathrm{Zn}$ groups $(P<0.01$, one-way ANOVA test $)$ 
the cleavage of PARP, from the full-length protein $(116 \mathrm{kDa})$ to the cleaved form $(85 \mathrm{kDa})$, was assessed by Western blot (Fig. 3b). In the control and the $15 \mu \mathrm{M} \mathrm{Zn}$ groups, caspase-3 activity was stable over the culture period; values were similar in the two groups (Fig. 3a, b).

The key event in the intrinsic apoptotic pathway is the release of cytochrome $c$, a component of the mitochondrial respiratory chain, to the cytosol where it activates Apaf-1 leading to the subsequent activation of caspase-9 and caspase-3. In support of the activation of this pathway in $\mathrm{Zn}$ deficiency, cytochrome $c$ levels were high in the cytosol of IMR-32 cells incubated in $1.5 \mu \mathrm{M} \mathrm{Zn}$ medium for $18 \mathrm{~h}$ (Fig. 3c). Accordingly, the mitochondrial content of the pro-apoptotic protein Bad, involved in the mitochondrial release of cytochrome $c$, was high in mitochondrial fractions, isolated from the Zn-deficient cells (Fig. 3c). Evaluation of DNA fragmentation, as assessed by TUNEL staining of DNA nicks and subsequent quantitation by cell cytometry, showed $45 \%$ of apoptotic cells after $48 \mathrm{~h}$ incubation in the $1.5 \mu \mathrm{M} \mathrm{Zn}$ medium (Fig. 3d). The increase in phosphatidylserine translocation was statistically significant after 48 and $72 \mathrm{~h}$ incubation in the $1.5 \mu \mathrm{M} \mathrm{Zn}$ medium, compared to cells incubated in control and $15 \mu \mathrm{M} \mathrm{Zn}$ media (Fig. 3e). DNA fragmentation and phosphatidyl serine externalization levels were similar for the control and $15 \mu \mathrm{M}$ Zn groups (Fig. 3d, e). Similar to the observations with the IMR-32 cells, a decrease in the availability of $\mathrm{Zn}$ induced apoptotic cell death in primary cultures of rat cortical neurons (Fig. 4a). Cortical neurons incubated in $1.5 \mu \mathrm{M} \mathrm{Zn}$ medium were characterized by low cell viability after $24 \mathrm{~h}$ incubation that was prevented by supplementing the chelated medium with $15 \mu \mathrm{M} \mathrm{Zn}$. Zn deficiency induced apoptotic cell death in rat cortical neurons, as evidenced by the activation of caspase-3 after $18 \mathrm{~h}$ incubation (Fig. 4b); and by high levels of DNA fragmentation after $24 \mathrm{~h}$, as evaluated by confocal microscopy (Fig. 4c). The simultaneous incubation with $0.5 \mathrm{mM} \alpha$-lipoic acid did not prevent the activation of caspase- 3 that occurs when neuronal $\mathrm{Zn}$ decreases (Fig. 4b).

Neuronal Signaling Pathways Involved in the Triggering of Apoptosis When the Availability of $\mathrm{Zn}$ Decreases

The kinases ERK and Akt participate in the inhibition of the intrinsic apoptotic pathway, by phosphorylating Bad, which prevents its translocation to the mitochondria. We next investigated if the ERK/Akt/Bad pathways were involved in the induction of apoptosis when neuronal $\mathrm{Zn}$ decreases. After incubating IMR-32 and cortical neurons in Zn-deficient medium for $9 \mathrm{~h}$, phosphorylated ERK1/2 levels were low, compared to levels in cells incubated in control or $15 \mu \mathrm{M} \mathrm{Zn}$ media (Fig. 5a). At the same time, the levels of phosphorylated Akt were high in cortical neurons and IMR32 cells incubated in the $\mathrm{Zn}$-deficient medium compared to levels in controls (Fig. 5a). While Akt promotes cell survival through its ability to phosphorylate Bad at Ser136, ERK phosphorylates Bad at Ser112. In IMR-32 cells and rat cortical neurons incubated for $9 \mathrm{~h}$ in $1.5 \mu \mathrm{M} \mathrm{Zn}$ medium, the levels of Bad phosphorylated at Ser136 were high, whereas those of Bad phosphorylated at Ser112 were similar to those observed in control cells (Fig. 5b). These results suggest that Akt activation in the $\mathrm{Zn}$-deficient cells cannot counteract the pro-apoptotic consequences of ERK inhibition.

We previously demonstrated that $\mathrm{Zn}$ deficiency can decrease the nuclear translocation of transcription factor $\mathrm{NF}-\kappa \mathrm{B}$ into the nucleus, inhibiting the NF- $\kappa \mathrm{B}$-regulated expression of select genes (Mackenzie et al. 2002b). As expected, NF- $\kappa \mathrm{B}-\mathrm{DNA}$ binding was lower in nuclear fractions from IMR-32 and rat cortical neurons incubated in $1.5 \mu \mathrm{M} \mathrm{Zn}$ medium for 36 and $24 \mathrm{~h}$, respectively, compared to controls (Fig. 6a). Several proteins (c-IAP-1, XIAP, Bcl-xL, and Bcl-2) involved in the protection of cells from apoptosis are regulated by NF- $\kappa$ B. c-IAP1 acts inhibiting caspases, XIAP exerts its anti-apoptotic action through the interaction with several partners (caspase-3, caspase-9, DIABLO/Smac) and Bcl-xL and Bcl-2 inhibit apoptosis by preventing the opening of the mitochondrial pore. Thus, we next investigated the effects of varying extracellular $\mathrm{Zn}$ concentrations on the expression of NF- $\kappa$ B-regulated anti-apoptotic proteins. In IMR-32 and rat cortical neurons incubated in $\mathrm{Zn}$-deficient medium for 36 and $24 \mathrm{~h}$, respectively, a decreased content of c-IAP1, XIAP, Bcl-xL, and Bcl-2 was observed in cortical neurons and of XIAP and Bcl-2 in IMR-32 cells (Fig. 6b). These findings support a role of $\mathrm{NF}-\kappa \mathrm{B}$ inhibition in the triggering of apoptosis when neuronal $\mathrm{Zn}$ availability decreases.

\section{Discussion}

In this study, we demonstrate Zn modulates neuronal proliferation and survival. A deficit of $\mathrm{Zn}$ can result in an inhibition of neuronal cell proliferation secondary to an arrest at the $G_{0} / G_{1}$ phase of the cell cycle. In proliferating as well as in quiescent neurons, $\mathrm{Zn}$ deficiency can trigger apoptotic neuronal death. Apoptosis occurs through the intrinsic pathway which can be a consequence of ERK inhibition, caspase- 3 activation, and the down-regulation of $\mathrm{NF}-\kappa \mathrm{B}$-dependent anti-apoptotic genes.

Under the conditions employed in this study, $\mathrm{Zn}$ deficiency caused an arrest in IMR-32 cell cycle progression at the $\mathrm{G}_{0} / \mathrm{G}_{1}$ phase. A similar finding was observed in HepG2 human hepatoblastoma cells (Wong et al. 2007). Accordingly, male rats fed a $\mathrm{Zn}$-deficient diet have a decreased 

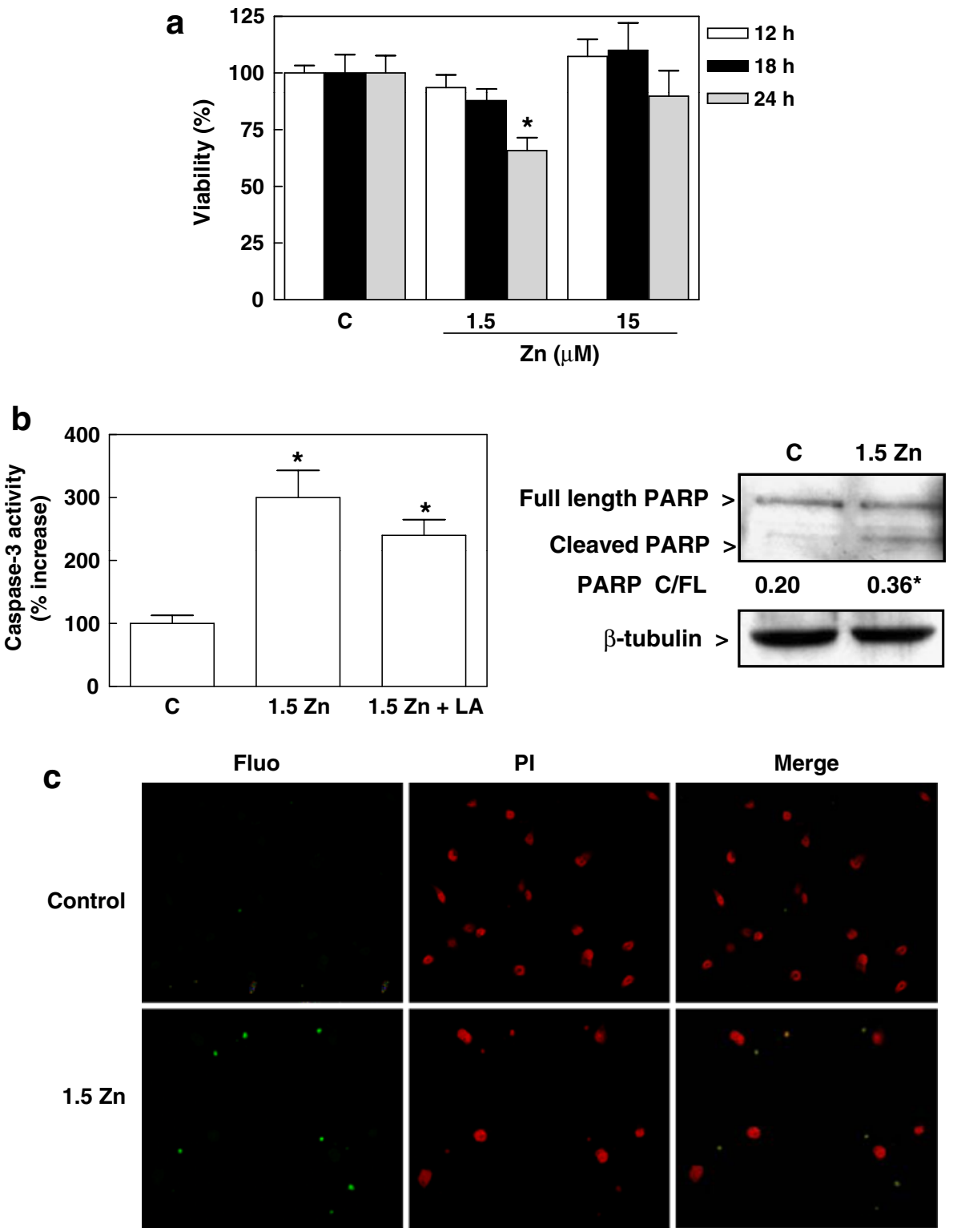

Fig. $4 \mathrm{Zn}$ deficiency induces apoptotic cell death in rat cortical neurons. Rat cortical neurons were incubated for 12,18 , or $24 \mathrm{~h}$ in control non-chelated medium $(C)$ or chelated media containing 1.5 $(1.5 \mathrm{Zn})$ or $15 \mu \mathrm{M}(15 \mathrm{Zn}) \mathrm{Zn}$. a Cell viability was measured as described in "Materials and methods" section. Results are shown as means \pm SEM of four independent experiments. * Significantly different compared to $C$ and $15 \mu \mathrm{M} \mathrm{Zn}$ groups $(P<0.01$, one-way ANOVA test). b (Left panel) Caspase-3 activity was measured after $18 \mathrm{~h}$ incubation in control non-chelated medium $(C)$ or chelated medium containing $1.5 \mu \mathrm{M} \mathrm{Zn}$ without $(1.5 \mathrm{Zn})$ or with the addition

number of proliferating stem cells in the subgranular zone and granular cell layer of the dentate gyrus compared to controls (Corniola et al. 2008). A key aspect in the cell cycle regulation is the MAPK pathway, Raf/MEK/ERK1/2 that can be activated by mitogenic signals, cytokines, and growth factors (Steelman et al. 2004). The ERK signaling pathway is involved in the integration of environmental of $0.5 \mathrm{mM} \alpha$-lipoic acid. (Right panel) Western blot for full-length and cleaved-PARP in total cell extracts isolated from rat cortical neurons incubated for $18 \mathrm{~h}$ in the corresponding media. Results are shown as means \pm SEM (Fig. 3a, b left panel) or means (Fig. 3b right panel) of two to three independent experiments. * Significantly different compared to $C$ group $(P<0.05$, one-way ANOVA test). c Apoptotic cells were also visualized by TUNEL assay and fluorescence microscopy after incubating rat cortical neurons for $24 \mathrm{~h}$ in the corresponding media. Fluo fluorescein, PI propidium iodide fluorescence

signals (nutrients, mitogens, and cytostatic factors) that lead to DNA replication during the $\mathrm{S}$ phase, and in relaying the information to the cell cycle control system. ERK activation throughout $G_{1}$ is required for the cell entry into $S$ phase (Yamamoto et al. 2006). Zn deficiency caused a rapid inhibition of ERK1/2 phosphorylation in IMR-32 cells supporting a role of this pathway in the associated cell 
Fig. 5 Signaling pathways involved in $\mathrm{Zn}$ deficiencyinduced apoptotic cell death. IMR-32 cells (left panels) and rat cortical neurons (right panels) were incubated in control non-chelated media $(C)$ or chelated media containing $1.5(1.5 \mathrm{Zn})$ or $15 \mu \mathrm{M}(15 \mathrm{Zn})$ $\mathrm{Zn}$ (for IMR-32 cells) for different periods of time. a Western blots for phosphorylated ERK1/2 (p-ERK1/2), ERK1/2, phosphorylated Akt (p-Akt), and Akt after $9 \mathrm{~h}$ incubation. b Western blots for phosphorylated $\mathrm{Bad}$ at serine 136 [p-Bad (Ser 136)] or serine 112 [p-Bad (Ser 112)]. After quantitation results are expressed as the ratio phosphorylated/nonphosphorylated protein. All results are shown as means \pm SEM of three to four independent experiments.

* Significantly different compared to $C$ and $15 \mu \mathrm{M} \mathrm{Zn}$ groups $(P<0.05$, one-way ANOVA test) a

IMR-32 cells
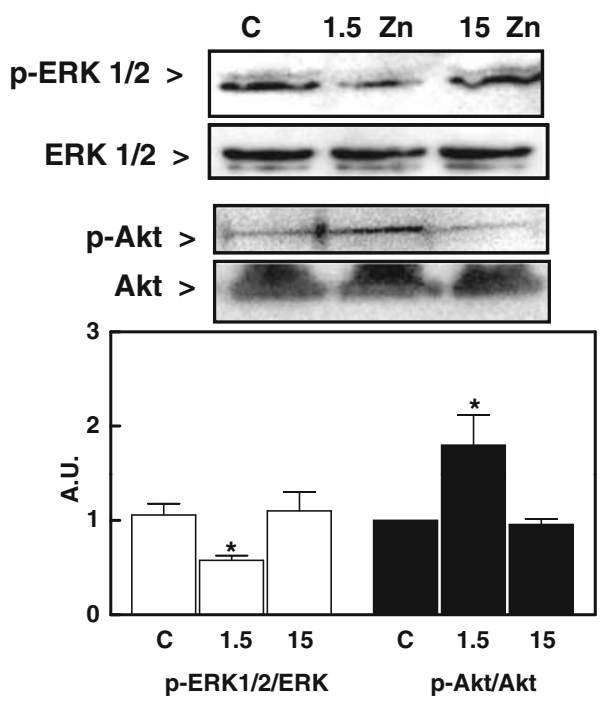

b

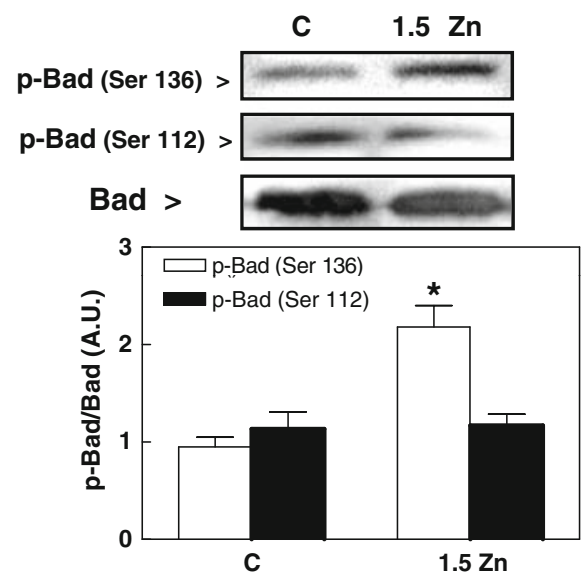

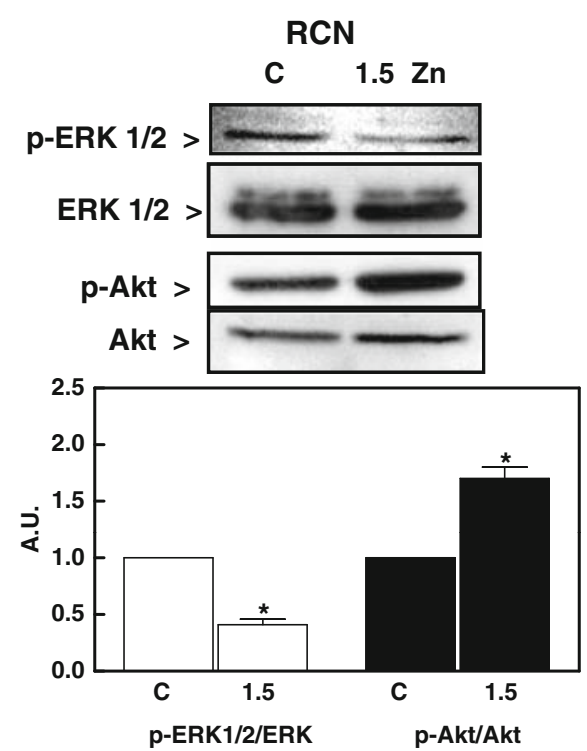

$\mathrm{RCN}$

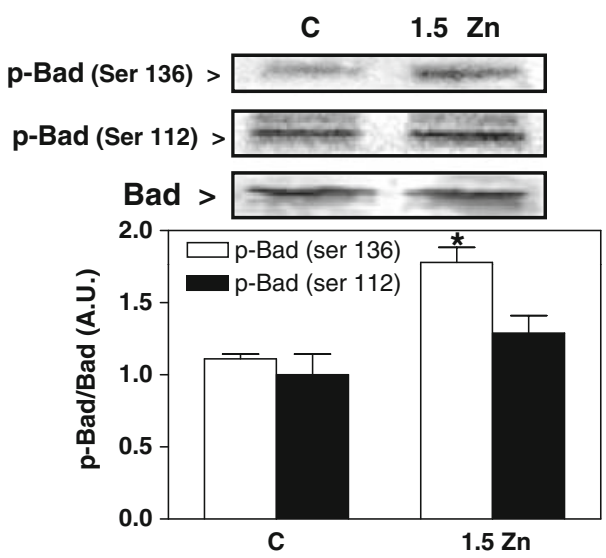

cycle arrest. Accordingly, the ERK inhibitor (PD 98059) causes a significant decrease in IMR-32 cell viability within $24 \mathrm{~h}$ (Zago et al. 2005), supporting a role of ERK in IMR-32 cell proliferation. A down-regulation of cyclins D and $\mathrm{E}$ was also observed in $\mathrm{Zn}$-deficient cells. Major components of the regulation of $G_{1}$ to phase $S$ transition are the cyclin-dependent kinases (Cdks) and their regulatory cyclins (Sherr 2000). During the $G_{1}$ phase, cyclin D assembles with its catalytic partners Cdk4 or Cdk6 which in turn phosphorylate members of the retinoblastoma family of proteins. Cyclin E-Cdk2 activates later in $G_{1}$ phase. Because ERK upregulates cyclins D1 and E, the findings of decreased cyclins D1 and E levels in the Zn-deficient IMR-32 cells are consistent with the observed ERK inhibition and $\mathrm{Go} / \mathrm{G}_{1}$ arrest. $\mathrm{Zn}$ deficiency also increased p53 protein levels which can occur as a consequence of $\mathrm{Zn}$ deficiency-induced activation of the MAPK (JNK/p-38)-AP-1 signaling pathway (Zago et al. 2005). As previously proposed (Corniola et al. 2008), Zn deficiencyinduced p53 upregulation can underlie an increased expression of downstream target genes which could contribute to the triggering of cell cycle arrest (Cdk inhibitor p21, and others) and apoptosis (Corniola et al. 2008; Miyashita and Reed 1995; Miyashita et al. 1994).

Other molecular events may contribute to the decreased cell proliferation in the Zn-deficient neuronal cells. It has been proposed that the regulation of the cell cycle by $\mathrm{Zn}$ could be secondary to its requirement for enzyme systems that influence cell division and proliferation (Clegg et al. 1989; MacDonald 2000; Beyersmann and Haase 2001), and to the impaired tubulin polymerization that is associated with $\mathrm{Zn}$ deficiency (Oteiza et al. 1990). An altered neuronal microtubule assembly (Mackenzie et al. 2002b) could impair the formation of the mitotic spindle affecting mitosis.

$\mathrm{Zn}$ deficiency induced apoptotic cell death in IMR-32 cells and in cortical neurons as evidenced by caspase- 3 
a

IMR-32 cells

RCN
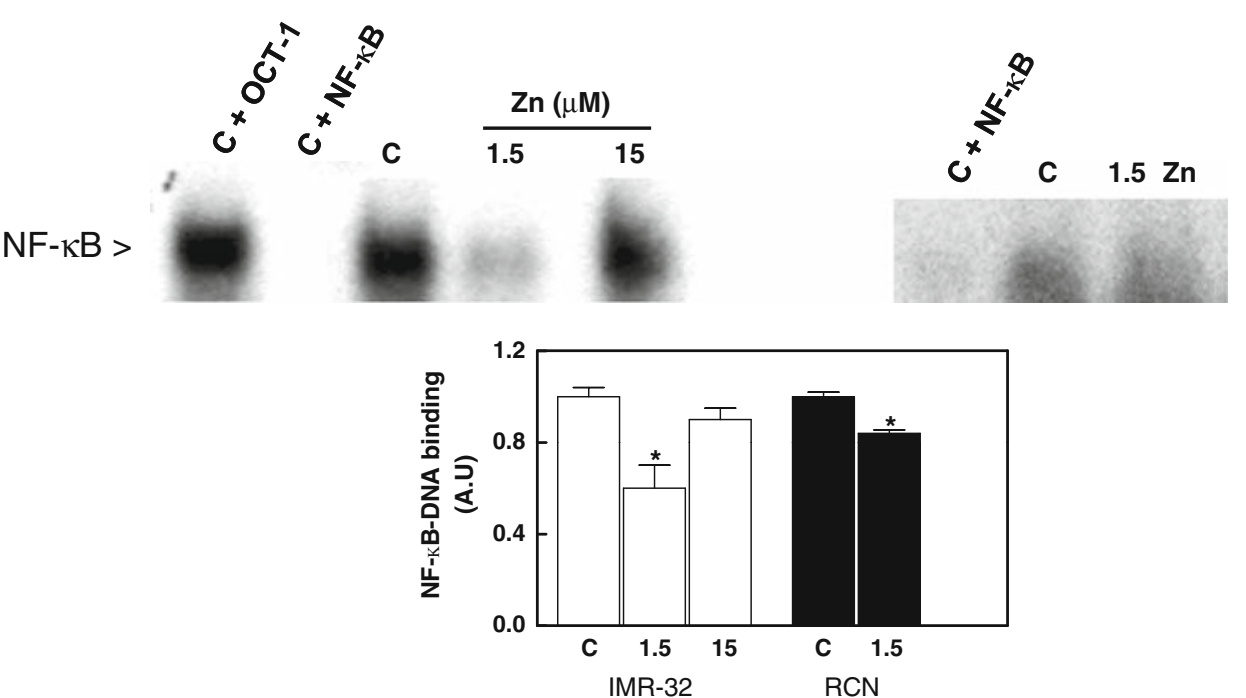

b

$$
\text { IMR-32 cells }
$$
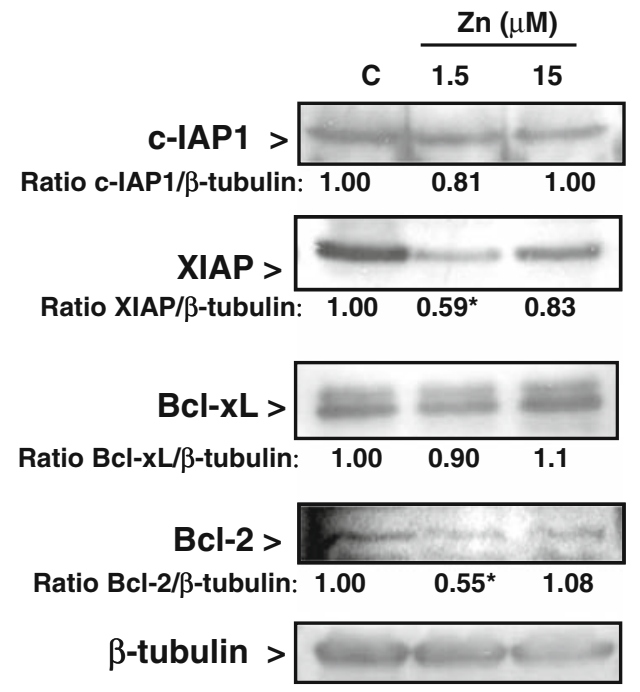

Fig. $6 \mathrm{Zn}$ deficiency inhibits the expression of antiapoptotic proteins. IMR-32 cells and rat cortical neurons $(\mathrm{RCN})$ were incubated in control non-chelated media $(C)$ or chelated media containing 1.5 or $15 \mu \mathrm{M} \mathrm{Zn}$ (for IMR-32 cells) or chelated media containing $1.5 \mu \mathrm{M}$ $\mathrm{Zn}(1.5 \mathrm{Zn})$ (for rat cortical neurons) for 36 and $24 \mathrm{~h}$, respectively. a EMSA for NF- $\kappa$ B in nuclear fractions. To determine the specificity of the NF- $\kappa \mathrm{B}-\mathrm{DNA}$ complex, the control nuclear fraction $(C)$ was incubated in the presence of 100-fold molar excess of unlabeled oligonucleotide containing the consensus sequence for either NF- $\kappa \mathrm{B}$ $(\mathrm{C}+\mathrm{NF}-\kappa \mathrm{B})$ or OCT -1 (C+ OCT -1$)$ before the binding assay. After the EMSA assays, bands were quantitated and values referred to

activation, phosphatidylserine externalization, and DNA fragmentation. Apoptotic cell death is consistently associated with $\mathrm{Zn}$ deficiency in animal as well as cell models (Fraker and Telford 1997; Jankowski-Hennig et al. 2000; Duffy et al. 2001; Truong-Tran et al. 2001; Clegg et al. 2005; Fraker 2005; Corniola et al. 2008). Different hypothesis have been reported for the induction of

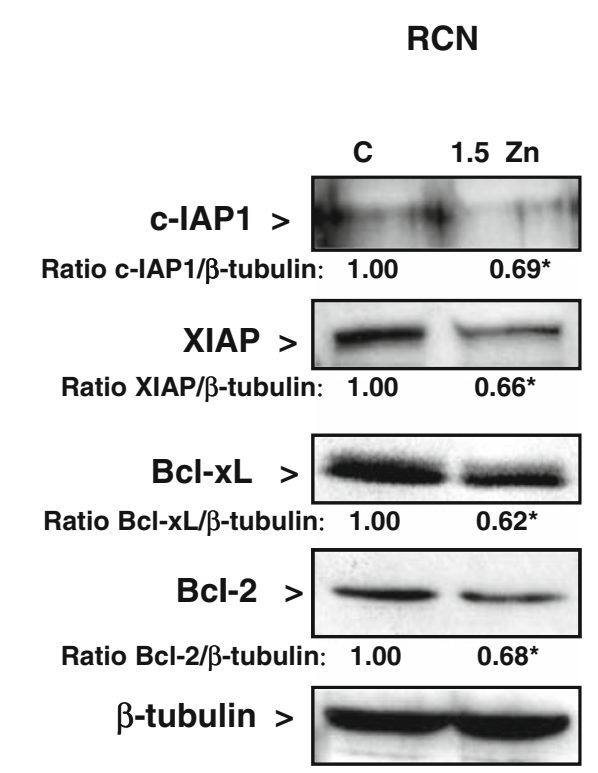

controls. Results are shown as means \pm SEM of three independent experiments. * Significantly different compared to the $C$ and $15 \mu \mathrm{M}$ $\mathrm{Zn}$ groups $(P<0.05$, one-way ANOVA test $)$. b The content of different antiapoptotic proteins was evaluated by Western blot in total cell fractions isolated from IMR-32 cells (left panel) or rat cortical neurons (right panel) as described in "Materials and methods" section. Representative images out of two to three independent experiments are shown. Numbers under the figures are means from two to three independent experiments. * Significantly different $(P<0.05)$ compared to controls

apoptosis when cellular $\mathrm{Zn}$ decreases. These include the action of $\mathrm{Zn}$ as a direct caspase regulator, alterations in receptor tyrosine kinase signaling, mitochondrial dysfunction, and increased oxidative stress (Truong-Tran et al. 2001; Clegg et al. 2005).

We previously observed that the increase in cell oxidants and the associated activation of JNK/p38/AP- 1 is not 
a critical trigger for the neuronal cell death that occurs following the induction of Zn deficiency in IMR-32 cells (Zago et al. 2005). Although treatment with $\alpha$-lipoic acid completely prevents the increase in oxidants in IMR-32 cells (Mackenzie et al. 2006b), it did not prevent caspase-3 activation in IMR-32 cells and cortical neurons. This provides further evidence that oxidative stress does not play a major role on $\mathrm{Zn}$ deficiency-induced neuronal apoptosis.

In this study, we observed a hypophosphorylation of ERK1/2 and an increased phosphorylation of Akt in association with $\mathrm{Zn}$ deficiency in IMR-32 and rat cortical neurons. Concomitantly, the levels of Bad phosphorylated at Ser-136 were high and no changes in the levels of Bad phosphorylated at Ser-112 were observed in association with Zn deficiency in either cell type, compared to controls. The Bcl-2 family of proteins includes anti-apoptotic and proapoptotic proteins, Bcl-2, and Bcl-X1 mediate cell survival while Bad and Bax induce cell death. Bad resides in the cytosol, as an inactive complex with the chaperone 14-3-3 proteins, when it is phosphorylated in at least three serine residues (Ser-112, 136, and 155) (Zha et al. 1996). These sites are phosphorylated by different kinases. The phosphorylation of Bad at Ser-112 is mediated by ERK (Zhu et al. 2002) and protein kinase A (Yang et al. 2005), Ser-136 is phosphorylated by Akt (Blume-Jensen et al. 1998), and Ser155 by protein kinase A (Virdee et al. 2000). Recent evidence shows that phosphorylation at the three different sites are required to prevent $\mathrm{Bad}$ translocation to the mitochondria (Wang et al. 2007). Thus, while Akt can be activated secondary to $\mathrm{Zn}$ deficiency, the inhibition of ERK can drive Bad translocation, and the subsequent mitochondrial release of cytochrome $c$ and caspase- 3 activation. The activation of caspase- 3 observed in IMR-32 cells and cortical neurons can also be due to the direct inhibitory action of $\mathrm{Zn}$ on the enzyme. In this regard, caspase- 3 is rapidly and directly activated by $\mathrm{Zn}$ chelation in HeLa cells without a requirement for an upstream event (Chimienti et al. 2001).

The inhibition of the pro-survival transcription factor NF- $\kappa \mathrm{B}$ could also contribute to $\mathrm{Zn}$ deficiency-induced neuronal apoptosis. The inhibition of NF- $\kappa \mathrm{B}$ with the proteasome inhibitor lactacystin causes apoptosis in IMR32 cells (Mackenzie et al. 2002a, 2006a). We previously described that $\mathrm{Zn}$ deficiency alters NF- $\kappa \mathrm{B}$ modulation and inhibits NF- $\kappa \mathrm{B}$-dependent gene expression in IMR-32 cells (Mackenzie et al. 2002a, 2006a). Consistently, in IMR-32 cells and rat cortical neurons incubated in $\mathrm{Zn}$-deficient media, we observed a low NF- $\kappa \mathrm{B}$-DNA binding in nuclear fractions and a decreased expression of the anti-apoptotic proteins c-IAP1, XIAP, Bcl-xL, and Bcl-2.

In summary, $\mathrm{Zn}$ modulates a number of pro-survival (ERK, Akt, and NF- $\kappa \mathrm{B}$ ) and pro-apoptotic (JNK and p53) pathways, and the final consequence of a deficit of $\mathrm{Zn}$ will be the result of the balance between the activation/

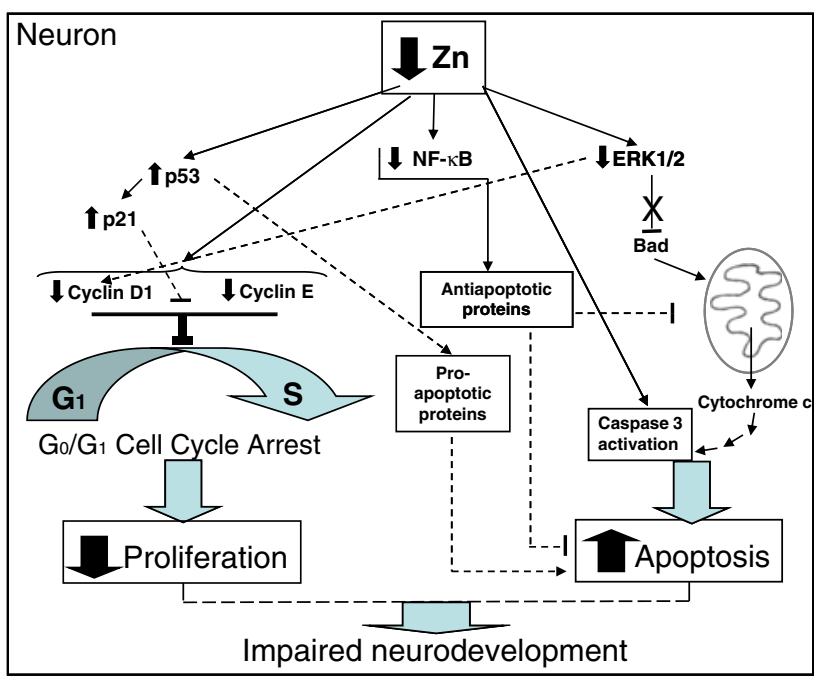

Fig. 7 Proposed mechanisms for $\mathrm{Zn}$ deficiency-induced decrease in cell proliferation and induction of apoptosis. Solid lines indicate events demonstrated in the current work, doted lines indicate proposed mechanisms leading to neuronal cell cycle arrest, decreased proliferation and induction of apoptosis as a consequence of a decreased $\mathrm{Zn}$ availability

inhibition of all of them. In neurons (Fig. 7), a low Zn availability results in decreased neuronal proliferation, due to an arrest of the cell cycle in $\mathrm{G}_{0} / \mathrm{G}_{1}$ phase, and the triggering of neuronal apoptosis. The inhibition of ERK is an important player in both processes. Caspase- 3 activation, as a direct consequence of neuronal $\mathrm{Zn}$ decrease, is a central event in the triggering of apoptosis. However, alterations in cell signals (NF- $\kappa \mathrm{B}, \mathrm{p} 53)$ that regulate the expression of pro-survival or pro-apoptotic genes can also contribute to $\mathrm{Zn}$ deficiency-induced apoptosis. Given the relevance of neuronal proliferation and apoptosis in the developmental shaping of the brain, a suboptimal $\mathrm{Zn}$ nutrition during embryogenesis and early postnatal life can be a significant risk to the conceptus.

Acknowledgments This study was supported by grants from the US National Institutes of Health (Grant \# HD 01743) and the University of California, Davis, and the University of Buenos Aires and CONICET, Argentina. We are very thankful to Joel Commisso for his assistance with the $\mathrm{Zn}$ measurements. We thank Dr. Laura Borodinsky for her support in the confocal microscope measurements.

Open Access This article is distributed under the terms of the Creative Commons Attribution Noncommercial License which permits any noncommercial use, distribution, and reproduction in any medium, provided the original author(s) and source are credited.

\section{References}

Banker G, Goslin K (eds) (1998) Culturing nerve cells, 2nd edn. MIT, Cambridge, MA, pp 11-36

Bentley ME, Caulfield LE, Ram M, Santizo MC, Hurtado E, Rivera JA, Ruel MT, Brown KH (1997) Zinc supplementation affects 
the activity patterns of rural Guatemalan infants. J Nutr 127:1333-1338

Beyersmann D, Haase H (2001) Functions of zinc in signaling, proliferation and differentiation of mammalian cells. Biometals 14:331-341

Blume-Jensen P, Janknecht R, Hunter T (1998) The kit receptor promotes cell survival via activation of PI 3-kinase and subsequent Akt-mediated phosphorylation of Bad on Ser136. Curr Biol 8:779-782

Bradford MM (1976) A rapid and sensitive method for the quantitation of microgram quantities of protein utilizing the principle of protein-dye binding. Anal Biochem 72:248-254

Chimienti F, Seve M, Richard S, Mathieu J, Favier A (2001) Role of cellular zinc in programmed cell death: temporal relationship between zinc depletion, activation of caspases, and cleavage of Sp family transcription factors. Biochem Pharmacol 62:51-62

Clegg MS, Keen CL, Hurley LS (1989) Biochemical pathologies of zinc deficiency. In: Mills CF (ed) Zinc in human biology. Springer-Verlag, New York, pp 129-145

Clegg MS, Hanna LA, Niles BJ, Momma TY, Keen CL (2005) Zinc deficiency-induced cell death. IUBMB Life 57:661-669

Corniola RS, Tassabehji NM, Hare J, Sharma G, Levenson CW (2008) Zinc deficiency impairs neuronal precursor cell proliferation and induces apoptosis via p53-mediated mechanisms. Brain Res 1237:52-61

Duffy JY, Miller CM, Rutschilling GL, Ridder GM, Clegg MS, Keen CL, Daston GP (2001) A decrease in intracellular zinc level precedes the detection of early indicators of apoptosis in HL-60 cells. Apoptosis 6:161-172

Dvergsten CL, Fosmire GJ, Ollerich DA, Sandstead HH (1983) Alterations in the postnatal development of the cerebellar cortex due to zinc deficiency. I. Impaired acquisition of granule cells. Brain Res 271:217-226

Dvergsten CL, Johnson LA, Sandstead HH (1984a) Alterations in the postnatal development of the cerebellar cortex due to zinc deficiency. III. Impaired dendritic differentiation of basket and stellate cells. Brain Res 318:21-26

Dvergsten CL, Fosmire GJ, Ollerich DA, Sandstead HH (1984b) Alterations in the postnatal development of the cerebellar cortex due to zinc deficiency. II. Impaired maturation of Purkinje cells. Brain Res 318:11-20

Fraker PJ (2005) Roles for cell death in zinc deficiency. J Nutr 135:359-362

Fraker PJ, Telford WG (1997) A reappraisal of the role of zinc in life and death decisions of cells. Proc Soc Exp Biol Med 215:229236

Frederickson CJ, Koh JY, Bush AI (2005) The neurobiology of zinc in health and disease. Nat Rev Neurosci 6:449-462

Gardner JM, Powell CA, Baker-Henningham H, Walker SP, Cole TJ, Grantham-McGregor SM (2005) Zinc supplementation and psychosocial stimulation: effects on the development of undernourished Jamaican children. Am J Clin Nutr 82:399-405

Goldenberg RL, Tamura T, Neggers Y, Copper RL, Johnston KE, DuBard MB, Hauth JC (1995) The effect of zinc supplementation on pregnancy outcome. JAMA 274:463-468

Golub MS, Keen CL, Gershwin ME, Hendrickx AG (1995) Developmental zinc deficiency and behavior. J Nutr 125:2263S-2271S

Golub MS, Keen CL, Gershwin ME (2000) Moderate zinc-iron deprivation influences behavior but not growth in adolescent rhesus monkeys. J Nutr 130:354S-357S

Hurley LS, Swenerton H (1966) Congenital malformations resulting from zinc deficiency in rats. Proc Soc Exp Biol Med 123:692696

Jankowski-Hennig MA, Clegg MS, Daston GP, Rogers JM, Keen CL (2000) Zinc-deficient rat embryos have increased caspase 3-like activity and apoptosis. Biochem Biophys Res Commun 271: 250-256

Keen CL, Taubeneck MW, Daston GP, Gershwin ME, Ansari A, Rogers J (1995) Primary and secondary Zn deficiency as factors contributing to abnormal central nervous system development. Dev Brain Dysfunct 8:79-89

Kirksey A, Wachs TD, Yunis F, Srinath U, Rahmanifar A, McCabe GP, Galal OM, Harrison GG, Jerome NW (1994) Relation of maternal zinc nutriture to pregnancy outcome and infant development in an Egyptian village. Am J Clin Nutr 60:782-792

Laemmli UK (1970) Cleavage of structural proteins during the assembly of the head of bacteriophage T4. Nature 227:680-685

Lagiou P, Mucci L, Tamimi R, Kuper H, Lagiou A, Hsieh CC, Trichopoulos D (2005) Micronutrient intake during pregnancy in relation to birth size. Eur J Nutr 44:52-59

MacDonald RS (2000) The role of zinc in growth and cell proliferation. J Nutr 130:1500S-1508S

MacDonald RS, Wollard-Biddle LC, Browning JD, Thornton WH Jr, O'Dell BL (1998) Zinc deprivation of murine 3T3 cells by use of diethylenetrinitrilopentaacetate impairs DNA synthesis upon stimulation with insulin-like growth factor-1 (IGF-1). J Nutr 128:1600-1605

Mackenzie GG, Keen CL, Oteiza PI (2002a) Zinc status of human IMR-32 neuroblastoma cells influences their susceptibility to iron-induced oxidative stress. Dev Neurosci 24:125-133

Mackenzie GG, Zago MP, Keen CL, Oteiza PI (2002b) Low intracellular zinc impairs the translocation of activated NF-kappa $\mathrm{B}$ to the nuclei in human neuroblastoma IMR-32 cells. J Biol Chem 277:34610-34617

Mackenzie GG, Keen CL, Oteiza PI (2006a) Microtubules are required for NF-kappaB nuclear translocation in neuroblastoma IMR-32 cells: modulation by zinc. J Neurochem 99:402-415

Mackenzie GG, Zago MP, Erlejman AG, Aimo L, Keen CL, Oteiza PI (2006b) Alpha-lipoic acid and $\mathrm{N}$-acetyl cysteine prevent zinc deficiency-induced activation of NF-kappaB and AP-1 transcription factors in human neuroblastoma IMR-32 cells. Free Radic Res 40:75-84

Miyashita T, Reed JC (1995) Tumor suppressor p53 is a direct transcriptional activator of the human bax gene. Cell 80:293-299

Miyashita T, Harigai M, Hanada M, Reed JC (1994) Identification of a p53-dependent negative response element in the bcl-2 gene. Cancer Res 54:3131-3135

Ninh NX, Maiter D, Verniers J, Lause P, Ketelslegers JM, Thissen JP (1998) Failure of exogenous IGF-I to restore normal growth in rats submitted to dietary zinc deprivation. J Endocrinol 159: $211-217$

Oteiza PI, Cuellar S, Lonnerdal B, Hurley LS, Keen CL (1990) Influence of maternal dietary zinc intake on in vitro tubulin polymerization in fetal rat brain. Teratology 41:97-104

Oteiza PI, Clegg MS, Zago MP, Keen CL (2000) Zinc deficiency induces oxidative stress and AP-1 activation in $3 \mathrm{~T} 3$ cells. Free Radic Biol Med 28:1091-1099

Penland JG, Sandstead HH, Alcock NW, Dayal HH, Chen XC, Li JS, Zhao F, Yang JJ (1997) A preliminary report: effects of zinc and micronutrient repletion on growth and neuropsychological function of urban Chinese children. J Am Coll Nutr 16:268-272

Rogers JM, Oteiza PI, Keen CL (1990) Zn and manganese deficiencies in prenatal and neonatal development with special reference to the central nervous system. Wiley-Liss, New York

Sandstead HH (2003) Zinc is essential for brain development and function. J Trace Elem Exp Med 16:165-173

Sherr CJ (2000) The Pezcoller lecture: cancer cell cycles revisited. Cancer Res 60:3689-3695

Steelman LS, Pohnert SC, Shelton JG, Franklin RA, Bertrand FE, McCubrey JA (2004) JAK/STAT, Raf/MEK/ERK, PI3 K/Akt 
and BCR-ABL in cell cycle progression and leukemogenesis. Leukemia 18:189-218

Truong-Tran AQ, Carter J, Ruffin RE, Zalewski PD (2001) The role of zinc in caspase activation and apoptotic cell death. Biometals $14: 315-330$

Truong-Tran AQ, Grosser D, Ruffin RE, Murgia C, Zalewski PD (2003) Apoptosis in the normal and inflamed airway epithelium: role of zinc in epithelial protection and procaspase-3 regulation. Biochem Pharmacol 66:1459-1468

Verstraeten SV, Zago MP, MacKenzie GG, Keen CL, Oteiza PI (2004) Influence of zinc deficiency on cell-membrane fluidity in Jurkat, 3T3 and IMR-32 cells. Biochem J 378:579-587

Virdee K, Parone PA, Tolkovsky AM (2000) Phosphorylation of the pro-apoptotic protein BAD on serine 155 , a novel site, contributes to cell survival. Curr Biol 10:1151-1154

Wang X, Fosmire GJ, Gay CV, Leach RM Jr (2002) Short-term zinc deficiency inhibits chondrocyte proliferation and induces cell apoptosis in the epiphyseal growth plate of young chickens. J Nutr 132:665-673

Wang XT, Pei DS, Xu J, Guan QH, Sun YF, Liu XM, Zhang GY (2007) Opposing effects of Bad phosphorylation at two distinct sites by Akt1 and JNK1/2 on ischemic brain injury. Cell Signal 19:1844-1856

Wong SH, Zhao Y, Schoene NW, Han CT, Shih RS, Lei KY (2007) Zinc deficiency depresses p21 gene expression: inhibition of cell cycle progression is independent of the decrease in $\mathrm{p} 21$ protein level in HepG2 cells. Am J Physiol Cell Physiol 292:C2175C2184

Yamamoto T, Ebisuya M, Ashida F, Okamoto K, Yonehara S, Nishida E (2006) Continuous ERK activation downregulates antiproliferative genes throughout G1 phase to allow cell-cycle progression. Curr Biol 16:1171-1182

Yang X, Liu L, Sternberg D, Tang L, Galinsky I, DeAngelo D, Stone R (2005) The FLT3 internal tandem duplication mutation prevents apoptosis in interleukin-3-deprived $\mathrm{BaF} 3$ cells due to protein kinase A and ribosomal S6 kinase 1-mediated BAD phosphorylation at serine 112. Cancer Res 65:7338-7347

Zago MP, Mackenzie GG, Adamo AM, Keen CL, Oteiza PI (2005) Differential modulation of MAP kinases by zinc deficiency in IMR-32 cells: role of $\mathrm{H}(2) \mathrm{O}(2)$. Antioxid Redox Signal 7:17731782

Zha J, Harada H, Yang E, Jockel J, Korsmeyer SJ (1996) Serine phosphorylation of death agonist BAD in response to survival factor results in binding to 14-3-3 not BCL-X(L). Cell 87:619628

Zhu Y, Yang GY, Ahlemeyer B, Pang L, Che XM, Culmsee C, Klumpp S, Krieglstein J (2002) Transforming growth factor-beta 1 increases bad phosphorylation and protects neurons against damage. J Neurosci 22:3898-3909 